\title{
Involutionary Rural Development and the Possibility of a Breakthrough: A Case Study of Gao Village
}

\author{
MOBO C. F. GAO
}

The post-Mao rural reforms have been generally accepted as a step forward in improving human conditions in rural China. It is true that in areas such as Guangdong, Zhejiang and Jiangsu improvement is impressive, though in other areas improvement has affected only a portion of the population. ${ }^{1}$ This study of one village, Gao Village, argues that in some areas rural life is not a clear-cut picture of total improvement since 1978. It shows that there are definite gains obtained in Mao's China that have been lost in the post-Mao period, and that de-collectivization cannot be taken for granted as a solution. ${ }^{2}$ Of course, a case study of Gao Village cannot be used for generalizations for all of China. One aim of the present study is to show the frustration of generalizations. Rural China cannot be taken as a single block, and what applies in one area may not apply elsewhere.

More importantly, this study shows that even in one village, it is not simply a case of either improvement or lack of improvement. Each period of development is characterized by gains in some aspects and losses in other aspects in rural life. While referring to some aspects of life before 1949 the paper focuses on comparing the developments of Gao Village during the Mao period with the post-Mao period. In the post-Mao period three development phases can be distinguished: the first phase during the late 1970s and early 1980s, the second phase during the late 1980s, and the third phase during the early 1990s. There were gains as well as losses in the first phase; there was definite deterioration in many aspect of rural life during the second phase and there are uncertainties and new prospects during the third phase.

By referring to life in Gao Village before 1949 and by comparing the commune period of Mao's China with the post-Mao reform period up to the end of the second phase, the paper argues that rural 
development since the 1950s in Gao Village has been in many ways involutionary: in terms of land holding, health care and living conditions, not much has changed in four decades. The paper does not claim that no progress has been made since 1949. The child mortality rate has been dramatically reduced, as a result of which, the population only doubled in forty years. Other progress such as availability of chemical fertilizers and new crops have contributed to the increase of grain production. However, the increased population living on the same amount of land means that improvements in living standards are hardly substantial. Forty years of development has brought Gao Village to where it began: a poverty trap and a struggle for survival. It was an involutionary development. ${ }^{3}$

When we come to the third phase, however, the picture looks radically different. Because of the stagnation of rural life and the increasing opportunities offered by the coastal industrial developments, many young villagers have left Gao Village as migrant workers. This fact has led to an increase of cash income for the village on the one hand and reduction of reliance on land on the other. As a result, the possibility of a breakthrough of involutionary development exists for the first time in Gao Village.

\section{Methodology}

I was born and brought up in Gao Village and lived there until 1973. My relatives are still living in that part of China and we have continued to have contacts with each other. The information and data contained in this study are based on written records, interviews and correspondence as well as diaries, recollections and personal experiences. While personal recollections and experiences cannot be replicated, similar information and data can be obtained by conducting field work in Gao Village or any neighbouring village if there is no official interference.

This paper is also based on two field work trips to Gao Village. One trip was made during the end of 1992 and early 1993 and another was made from April to May 1994. Each trip lasted about a month, and in-depth interviews were conducted with the elderly villagers who recollected their days in Mao's China as well as their life before 1949. Former commune, production brigade and production team leaders, present village heads, local $x_{i a n g}{ }^{5}$ government of- 
Mobo C. F. Gao

ficials, and family members of the former landlord and rich peasant were also interviewed. In order to examine the "pull and push" factors of migrant workers and the social and economic consequences of migrant work, I also conducted interviews with Gao villagers who were working in Xiamen and Shenzhen. If figures are of any significance in this case the people interviewed during the two trips were no less than one hundred. ${ }^{6}$

\section{Gao Village: Some Background}

Gao Village is a small-sized village by local standards and now has a population of 318 (168 of them males) and arable land of $308 \mathrm{mu}{ }^{7} \mathrm{It}$ is located near China's second largest fresh water lake, the Boyang Lake, in Jiangxi Province. It is a remote village in the sense that it has no access to a railway line; nor has a water transportation system been developed though it is near a river that leads to the Boyang Lake. The village has not had a bus route until the late 1970s and most of the villagers do not travel anywhere further than several kilometres away by foot. The nearest town is Boyang County Town which is about 150 kilometres away. However, the village is not a remote mountainous place where there are hardly any people around. There are many villages surrounding Gao Village, most of them much bigger and some of them have more than one thousand households. Like Gao Village those surrounding villages are also one-surname clan villages.

Gao Village is one of these idyllic villages suitable for a selfsufficient economy: plenty of rainfall and four clear-cut seasons which provide a climate for growing all kinds of crops; hilly but not mountainous land where firewood can grow on dry land and rice can grow in paddy fields; and a river plus many ponds and creeks which can provide fish and water resources. The "self-sufficiency" in this area has been such that up to the present day there is not a single marketplace within the neighbourhood of three kilometres. The villagers do not have any memory of war. The Japanese never penetrated this area, nor had the military fighting between the Communists and the Nationalists affected the village.

When the Communists took over the village in 1949 it had $280 \mathrm{mu}$ of arable land which was distributed among twenty households. When the Land Reform started, one household was classified as 
landlord, another as rich peasant, twelve households as middle peasants and six as poor peasants. The average poor peasant household had about six mu of land; the average middle peasant household had about $13.8 \mathrm{mu}$ of land. The landlord had forty-five $m u$ of land and the rich peasant had thirty-three $m u$ of land. ${ }^{8}$ The landlord Gao Tianqiang was classified as a landlord largely because he did not work on the land he owned. He rented the land to some poor peasants while he worked as village sishou teacher. ${ }^{9}$

Land Reform was soon followed by the cooperatives. Then it was the commune system during which period the issue of land holding was of no importance for our discussion. The $308 \mathrm{mu}$ of land at present has been distributed equally among the villagers according to the number of people in each household. ${ }^{10}$ Usually, the land is redistributed every three to five years to accommodate the change of number of people in each household. However, the local authorities can decide to keep the distribution unchanged for a longer period of time though the government policy until 1993 was to encourage regular change in an attempt to adjust demographic changes, possibly for the reason of equity. ${ }^{11}$ In 1991, the household that has the biggest share of land had about fifteen $m u$ of land while the smallest share per household was about three $m u$ of land.

In relative terms, the present land holding is more equal than before 1949. However, in absolute terms the average household is worse off than before. At present, each household has an average of $6.2 \mathrm{mu}$ of land and each person has $0.96 \mathrm{mu}$ of land whereas before 1949 , even the poorest household had six $m u$ of land and each person had an average of $1.7 \mathrm{mu}$ of land. The reason is simply that by 1949 there were only 160 people and twenty households in the village while now there are 318 people and fifty-one households. By 1991, of all the households in the village, 60 percent were middle peasants who had an average of $13.8 \mathrm{mu}$ of land, ${ }^{12}$ which was only a little below that of the biggest "landowner" who had about fifteen $m u$ of land. The reason for the twofold increase in population is partly due to the reduction of child mortality, an issue to be discussed presently, and partly due the partial failure of the government's population control policy, the reason of which, again, is dealt with in the next section. The simple logic is that the land in the village cannot be expanded any further to accommodate the population growth. Therefore, there cannot be any improvement in land holding. 


\section{Developments Since 1949}

As we have seen, the population in Gao Village virtually doubled in forty years since 1949. The pattern of increase can be categorized into three periods: the first fourteen years from 1949 to 1963, the second fifteen years from 1963 to 1978 , and the third thirteen years from 1978 to 1991 . The four decades are so divided because they are related to different child mortality rates, health care systems and population control policies.

\section{Child Mortality}

From 1949 to 1963 , sixty babies were born, ${ }^{13}$ of which twenty-four died when they were children. The mortality rate was 40 percent. During the period from 1963 to 1978 , the mortality rate was 6.6 percent. From 1978 to 1991, the rate was seven percent. The mortality rate from 1963 to 1991 remained stable and the rate of mortality during the post-Mao reform period was slightly higher than that in the period from 1963 to 1978 in Mao's era. The high mortality rate during the period from 1949 to 1963 is perhaps not unexpected given that the period covers the Great Leap Forward, during which time the peasantry suffered the most in Mao's China. However, that is only part of the story, as we shall see shortly.

\section{Health Care System}

The period from 1958 until 1961 was the most difficult time in anybody's memory for the Gao villagers. It was in those years that a woman hanged herself because of family difficulties. It certainly was not the best of times to have babies. However, a possible explanation for the high mortality rate during the period of fourteen years from 1949 to 1963 lies largely, if not completely, in the lack of a health care system. Until 1962, there had not been a single doctor of any qualification in modern medicine within a fifty kilometres neighbourhood. Just as in the years before 1949, there was not any medical treatment for simple illness such as pertussis, malaria, diarrhoea, let alone pneumonia or hepatitis. If a child fell ill, the parents had only two resorts: To pray to the Buddha or to seek a Chinese traditional medicine doctor who was usually self-trained and inclined to perform all kinds of dubious practices. Unless it could build up its own resistance, the choice for a sick child was virtually waiting for death. ${ }^{14}$ Since the 1960 s the situation dramatically improved because 
vaccination for common deceases such as cholera, measles, smallpox, mumps and encephalitis was introduced to the village. Secondly, two doctors who practiced both Chinese and Western medicine were sent by the government to be stationed in Gao Village in $1963 .^{15}$ These two doctors also trained a boy from the village who, when the two old doctors left, worked as a "barefoot" doctor in the village during the Cultural Revolution. Evidently, the dramatic reduction in child mortality rate was more a result of the accessibility to modern medicine than a change in the economic system. ${ }^{16}$

As for health care, the years between 1963 and 1978 were Gao Village's golden time. With little cost before the Cultural Revolution and virtually nothing during the Cultural Revolution the villagers had access to a medical system that basically worked. However, since the post-Mao reforms the situation began to change. With the abolition of the "barefoot" doctor system, medical practice became privatized. There are now three doctors for about five thousand people in nine villages. None of the doctors is stationed in Gao Village and the nearest medical clinic is two kilometres away. According to the village committee's estimate, 20 percent of the families in Gao Village do not go to see the doctor simply because they cannot afford it. ${ }^{17}$ The practice of praying before the Buddha has started to thrive again. Whether the slight increase of mortality rate in the post- Mao period has anything to do with the change in the health care system cannot be firmly established; but the difficulties facing some of the villagers are real and acute.

\section{Population Control}

The major theme of the paper is that within the framework of the present economic structure the incorrigible demand on the limited amount of land by the increasing population makes any substantial improvement in living standards difficult. The variables involved in the population index are very complex. Let us consider three most obvious variables: cultural tradition, government policy and social security. It certainly is the case in Gao Village that the tradition of requiring a male to carry on the family tree is a very strong factor that influences population growth. Gao Changxian, for instance, now has three children, with two girls born first and second. He would not stop until he had the third child that was a boy. It is a built-in common sense in Confucian ideology that the more children one has the happier one's family will be. But we have to remember 
that cultural influence has been a consistent factor, and, if anything, this traditional influence should have been weakened by forty years of Communist rule. Therefore, traditional influence does not tell us all about the variation of population growth in Gao Village.

The second factor is that a measure of security is important. At the time when modern medicine was not available one rationale for having more children was that because children are an insurance measure for old age more children are needed because some may die. With the reduction of the child mortality rate the rationale for having more children as a security measure is not so acute since the chance of the child surviving is very big. However, a girl in the family does not provide security for the parents because she will marry away. Therefore, the need of a boy usually means a larger family. Finally, government policy is certainly instrumental in population growth in Gao Village. However, because of the dismantling of the commune system and the distribution of land to individual households, there are factors which work against the government's policy of population control. One such factor is that it has taken away much of the power that the local cadres used to have over the peasants and therefore deprived the grass-root organisation of an effective mechanism to carry out a population control policy except by brute force. ${ }^{18}$ Another factor is that it has given the peasants a strong incentive to produce more children. The peasants want to have more children, in fact the more the better, because until the 1990s land in Gao Village had been distributed to each household according to nothing but the number of people. ${ }^{19}$

\section{Education}

The post-Mao reform policies have had detrimental effects on education. During the 1963 to 1978 period, Gao Village had one university student, eleven middle school students, fifteen primary school students up to grade five; and 86 percent of all the children under the age of sixteen had finished schooling up to grade three. However, from 1978 to 1991, there were only five middle school students, nine primary school students up to grade five; and only 51 percent of all the children under the age of sixteen had finished schooling up to grade three. ${ }^{20}$ There has not been a single university student since 1976. There was one university student from the village thanks to the "worker-peasant-soldier student" programme imposed by the radicals during the Cultural Revolution. Between 1949 and 1962, there 
was no one who attended school up to middle school level. However, the government did impose some kind of "literacy" evening classes on the adult population during the Great Leap Forward. ${ }^{21}$

Unless there is a career opportunity other than farming there was generally no incentive for a farmer to send a child to school in Gao Village. Until the early 1990 s almost ${ }^{22}$ everybody in Gao village was destined to work on the land and one does not need to be educated to carry out the kind of farming task that is done in traditional ways. Usually, girls suffer most because a family does not want to invest, if there is any incentive to invest at all, in a girl who is to be married away. However, girls fared much better during the period from 1963 to 1978 since 40 percent of the 86 percent of all children under the age of sixteen, who went to school, were girls. Of the fifteen children who had finished primary school at that time three were girls, which was 20 percent whereas between 1978 and 1991 none of the nine five-grade students were girls. ${ }^{23}$

A school catering for grade one, two and three was set up in 1972, again imposed by the Cultural Revolution policy, in Gao Village. Most children under the age of nine went to school at that time because it was convenient and, above all, it was virtually free. An equally important factor was that in the commune system, even a poor family was not compelled to make use of child labour, because everyone was guaranteed the same amount of food no matter how much work a family contributed to production activities. A village school of the same scale still functions today; and children at the age of six, seven and eight do attend the school. However, 90 percent of the female and 30 percent of the male children did not go to school beyond year three during the $1980 \mathrm{~s}^{24}$ in spite of the fact the Chinese government introduced the compulsory primary education law all over the country. ${ }^{25}$ This is the case because the post-Mao reform policies have had several consequences that are detrimental to education. One of them is that whoever sends a child to school is directly responsible for much of the cost. The government at present pays 30 percent of the teacher's salary. The rest of the cost, including textbooks and stationary, are paid for by the villagers themselves. In the 1960s and 1970s, the government was responsible for at least 50 percent of the teacher's salary plus some other costs. The rest of the cost was pooled together by the commune. ${ }^{26}$ As a result, a family did not have to pay for a child's education in cash, as it is the practice now. 
The other effect on education in consequence of the "responsibility system" is that a family is compelled to make full use of child labour. Child labour can be in the form of, for instance, grazing a buffalo, or baby-sitting a younger member in the family so that mother can go out to work. Some girls even cook for the family at the age of nine. Within the commune system, first there was no compelling reason for a family to make use of the child since every person was distributed an equal amount of food irrespective of how much the mother worked. Secondly, some work could be rationalized and therefore there was no need for child labour. Nowadays, for instance every family needs one person to graze the buffalo if the family owns one whereas in the commune system one or two people could look after all the buffalos in the village. During the early 1970s the village collectively built a school house. But when the de-collectivisation took place in the early 1980s the school house was dismantled for redistribution. Since then the teacher has to find classrooms in her or his own house.

\section{Living Standard}

The measurement of the living standard is, of course, complex. However, with a presentation below of various factors involved, a sketch can be drawn which shows that living standards have not been substantially improved either by Mao's revolution, or by the post-Mao reform until the 1990s.

Housing. Before 1949, there were twelve houses: eight large brick houses, two small brick houses and two mud houses. One of the small brick houses belonged to the teacher landlord and the other belonged to the rich peasant. Each of the large brick houses belonged to a clan of families who were either middle or poor peasants. In 1949, the Land Reform team confiscated the landlord's brick house and the landlord was moved to a mud house. Apart from that, housing ownership remained unchanged. The seven large brick houses, which were all of the same patterns with very thick brick walls, cool in summer and warm in winter, were particularly good for living. They all faced the south, with two spacious rooms on both the east and west sides and a rectangular room at the back. In the middle of each house there was a big hall, so big that the hall was divided into two parts by a huge skylight right in the middle of the roof through which when it rained water fell into a pool inside the 
house. The pool was built with elegant large slate stones under which water was channelled away. Attached to each of these houses, there was a small cottage used as a kitchen, usually for two or three families of the same clan.

With the increase of population since the 1960s, the existing houses became inadequate while the peasants had not been able to build new houses. What happened as a solution was that the peasants dismantled these ingeniously built large houses and used the materials to construct smaller houses for more families. From 1949 to 1978 two large brick houses were torn down in this way. From 1978 to 1991, another three of these houses were dismantled to build smaller houses to accommodate more people.

By the early 1990s, half of the households in Gao Village have built "new houses", albeit small and primitive. The bricks and wood from the old houses alone were not enough for the construction of these new houses. Two other factors contributed to this "real estate boom", which are discussed later in the paper. One factor is that during the early 1980s there was some substantial increase in income thanks to the price increase in agricultural produce. The other factor is the cash income from migrant workers.

There is only one really newly-built house that is of brick and cement and two storeys. That house was built during the post- Mao reform period by a "get rich first household". The man who owns that house was an orphan adopted by a villager in the early 1960s. It so happened that the boy's uncle is in the building industry in Jingdezhen, which is the oldest porcelain producing capital in China, two hundred kilometres away. Through his uncle's connections, the orphan boy, now grown-up, was able to contract a number of building works in the 1980s. He made his fortune by making full use of cheap village labour and became the village's only "Ten Thousand RMB Household".

Food Consumption and Diet Composition.There is a Chinese saying which goes: min yi shi wei tian. Tian "heaven" or "sky" is the biggest and most sacred thing in the world and min, the ordinary Chinese, take shi, which is food, as tian, that is, as the biggest and therefore the most important thing in the whole world. This is the case because the Chinese have never been far away from starvation. Although grain production has increased steadily since the 1960s the 
fundamental problem of feeding the population in Gao Village remains the same, if not worse, after forty years of development.

After the turmoil of the Great Leap Forward, the situation began to stabilize in Gao Village. Chemical fertilizers and new types of crops such as short stock rice crops were made available to the peasants. Short stock rice was accepted by the peasants because it can stand up to wind whereas long stock rice may fall to the muddy ground just before harvesting. The short stock also has the advantage of needing fewer days to grow. All this has indeed increased output. The average output of rice per $m u$ before 1949 was about two hundred kilograms whereas now one $m u$ of land can produce about five hundred kilograms. However, this increase was not just a result of the introduction of new technology. It was also the result of harder work. What happens is that, thanks to the shorter life span of the short stock rice, the peasants plant rice twice a year, once in spring and once in summer. It is the two harvests together that enables the peasants to produce five hundred kilograms of rice per $m u$. What this means is that the peasants work much harder than they used to do before 1949. The elderly always have a fond memory of not having to work so hard when they were young.

Because of the introduction of new technology, the farming costs are higher than before 1949. Chemicals cost dearly whereas previously all the peasants needed was recycling human and animal waste. The other consequence of having two harvests of rice in one piece of land is that the planting of winter economy crop on that same piece of land is extremely limited. As a result, the peasants' income as a whole suffers from the loss of other economy crops. And yet the peasants need the rice, which is the staple food, to feed the people.

The introduction of chemical fertilizers has had serious ecological consequences that have greatly affected the villager's way of life. There used to be a water resource system consisting of a number of creeks and dozens of ponds that were all channelled into a river which in turn runs towards the Boyang Lake. During the raining season in spring a variety of aquatic animals from the Lake migrated upwards to live and breed in the creeks and ponds. Fish, shrimps, crabs, shell fish, eels were the villagers' valuable food resource and it was free for all. Water weeds and aquatic vegetables of all kinds were a natural diet for pigs which in turn were a major source of oil, protein and organic fertilizer for the villagers. Frogs, which are natu- 
ral controllers of harmful insect to the rice crop, were also a source of food. Even twenty years ago, swimming while catching fish was a simple fact of life and joyful games for children. Now, thanks to the chemical fertilisers and insecticides, things have all changed. Fishing is not a routine any more in Gao village. A source of healthy and virtually free food has therefore disappeared. As a result, the villagers' diet composition has become less colourful and less healthy.

The poverty of the diet composition resulting from ecological destruction has not, of course, occurred overnight. It happened gradually and it is slightly compensated by improvement from other sources of nutrition during the 1990s. During the 1970s, an average villager consumed five kilograms of meat annually. ${ }^{27}$ Since 1978, the amount of meat the villagers can afford remained the same each year until the 1990s when the villagers have some disposable cash thanks to migrant workers. ${ }^{28}$ The villagers do raise pigs; but usually they have to sell their pigs to the state in return for cash. During the Spring Festival many families kill their pigs; but they can afford to retain only a small part of the meat for self-consumption. Both before and after the commune system the village has placed a ban on raising chickens because free range chickens destroy crops. When I visited the village, friends and relatives had to purchase eggs from the nearby market for me as a treat. The pattern of a poor diet began to change only in the early 1990s as a result of cash income from migrant workers.

Quality of Life and Consumer Goods. A noticeable improvement is the availability of consumer goods since the later 1980s. Even up to the later 1970s, the villagers would use cotton produced in their private plots to weave cloth for their own use. Every family used to have a traditional tool to make threads out of cotton. Women and girls would work, usually in winter, until midnight to make the threads. When enough threads had been made, a local craftsperson would be invited to the household to weave the cloth. There were two cloth weavers in Gao Village, a man and a woman. Then the farmers would use traditional technique to dye the cloth which was made into shirts, trousers, and padded coats. I can still remember that a white cotton shirt was a luxury because it needed frequent washing and therefore was less durable. Only the newly-wed bride could expect some cloth made from industrial fabric. In recent years, clothes have become much cheaper in comparison and no one in the village 
weaves cotton cloth any more. They all like to wear clothes made of synthetic fabrics which look modern and are easy to wash.

There are now forty-two bicycles in Gao Village whereas in the early 1980s there were only two and in the 1970s there was none. There was no electricity in the village until the late 1980s. There are now also one colour and fifteen black and white television sets in the village. Young people start to possess things like a watch. In the 1970 s this would be luxury unheard of. Some youngsters have started to wear Western style clothes brought back by their migrant working brothers or sisters from the outside world. Rubber boots are no longer a luxury as they used to be. Small consumer items such as a pair of gloves and socks, a torchlight, a hat and a scarf are no longer a major consideration in the family budget as they used to be.

However, we cannot simply take for granted that the increased consumption of commodity goods is an indication of increased income as a result of de-collectivisation. The picture is far more complex. For one thing, consumer goods are simply much cheaper now than, say, ten years ago, thanks to the industrial boom since the 1980s. For instance, an average ordinary watch costs around fifty RMB, or even less, nowadays whereas its cost was at least 120 RMB before 1978. The other factor to consider is that since the late 1980s Gao villagers have not increased their income from their agricultural work. Instead, the source of their cash income is from migrant workers which is further discussed below.

Quality of life is, of course, hard to measure. However, there are some ways of doing so, one of which is by way of comparison. With few exceptions, all the villagers born before 1949 are nostalgic about the good old days when life was easy and peaceful. All they can say about the only landlord in the village are good things: gentle, kind and helpful. ${ }^{29}$ In comparison, the local communist cadres, especially those who formed "the work teams" sent by the government from time to time during the communist rule of four decades, are bullies and brutal. What the villagers complain about most is the famine during the Great Leap Forward years, and the fact that now they have to work harder just to feed themselves and that still there is hunger from time to time.

The majority of Gao villagers are of middle peasant background and were doing fine before $1949 .{ }^{30}$ Compared with the old days they now live in worse housing conditions and yet they have to work 
harder. During the commune system they worked for longer hours, twelve hours a day during busy seasons and eight to nine hours a day during slack seasons, mostly engaged in organized irrigation work. The average number of working days were three hundred and thirty a year. ${ }^{31}$ The older villagers keep on saying that before 1949 they did not have to work more than three hundred days a year, with an average of eight hours a day. One of the reasons for so much work during the commune period is that there was always irrigation and infrastructure work organized by the commune. Since the dismantling of the commune system the work load in that respect has been gradually reduced almost to zero in Gao Village. But the fact remains that villagers have to plant rice twice a year, as opposed to once a year before the 1950s.

Apart from the destruction of aquatic life, the population pressure has had other environmental consequences. Before 1949, even in the early 1960s, there were bushes and small forests around the village where the children could play and where mushrooms and firewood could be picked. At that time, the villagers could use rice stock as firewood for cooking. However, with the introduction of short stock rice there was little rice stock to burn. With the increasing pressure of population, trees and bushes have gradually been cut for firewood. Now there are hardly any trees, let alone bushes.

Life before 1949 could not have been rosy for Gao Villagers; but the diet seemed to be richer before environmental destruction. Compared with the past there are now more natural disasters, especially floods, which occur more often these days. In fact, Gao Village experiences flooding every year since the later 1960s, sometimes minor and sometimes major. ${ }^{32}$ The explanation for this is not hard to find. With the increasing pressure of population, the peasants everywhere around the Boyang Lake started to reclaim arable land from the Lake and the rivers surrounding it. They have encircled the edges of these rivers and the Lake itself by building numerous dykes so that what was inside the dykes became rice fields. ${ }^{33}$ The net effect of this massive water work engineering is that during the rainy season, which is between late spring and early summer when the rice is about to be harvested, the water level in the Boyang Lake gets higher and higher while the water level inside the dykes is also rising to the extent that water pumps are unable to cope. Even when the dykes are strong enough to hold the water from outside, there is still flooding inside 
Mobo C. F. Gao

the dykes. Sometimes flooding from outside occurs even at the time when Gao Village is having a drought. This is the case because the area surrounding the Boyang Lake is so large that there is always somewhere where it rains. When flooding is serious, which is the case once every three years in Gao Village, the peasants go hungry. Sometimes when failures of crops become too serious as a result of having drought and flooding at the same time the villagers have to buy grain from the state in order to avoid famine. ${ }^{34}$

Working conditions have remained unchanged in four decades. The peasants still have to use the wooden plough pulled by a buffalo; they still plant rice bunch by bunch manually; they still thresh the rice manually by beating the rice stock against a wooden board. The villagers have never been able to buy a tractor or harvesting machine. In those days when everybody was working for the commune, hard work was compensated in a way by a spirit of cooperation. Because the villagers usually worked in groups, they could talk, joke and gossip while working. When they stopped to rest, they could tell stories. There was a collective culture which made the backbreaking labour less unpleasant and more bearable. The young villagers especially liked to work in groups. With the dismantling of the commune system, what is left is the stark necessity for each family to toil for survival.

During late 1960s and early 1970s life was much more colourful and the villagers began to enjoy recreation activities. From time to time school children were organized to perform dances and put up plays for the villagers. Loudspeakers were installed to broadcast news from home and abroad. The young people themselves were organized to perform the model Peking operas. It is true that all this was politically motivated and organized by the government. But for the villagers it was great entertainment through which they learned new things and experienced unprecedented cultural activities. There was also a boost of sports, again, something unprecedented. Table tennis was a great game for children and the village even constructed a basketball court, to the tremendous delight of the young people. During slack seasons and Spring Festivals friendly basketball matches were organized among the neighbouring villages. ${ }^{35}$

Thanks to the post-Mao reforms, nothing of this kind has ever been organized since $1978 .^{36}$ Whatever existed before has been abandoned. People hardly get together let alone organize cultural 
activities. The only time the villagers, especially the young ones, can look forward to activities is the Spring Festival each year when they visit relatives. Occasionally, the villagers may go and watch a traditional folk play performed by some theatrical group. The themes in those plays are usually, as Mao Zedong commented, about ghosts and emperors, which, though not less politically indoctrinating, are completely irrelevant to the villagers' desires and aspirations. Since the late 1980s, however, this is compensated by the accessibility of television.

Life Expectancy.There is no official record of life expectancy either before or after 1949. However, if memory is anything to go by, the lack of modern medicine did not mean that the villagers, once they survived as children, lived a shorter life. Indeed, the old villagers count on their fingers and concluded that in the old days an average person (discounting child mortality) lived up to the age of sixty-five. ${ }^{37}$ According to official statistics since 1949, although even the famine during the Great Leap Forward did not claim any life except a woman who hanged herself, an average adult villager died at approximately the age of sixty. However, life expectancy is much longer since the late 1960s because of the reduction of the child mortality rate. ${ }^{38}$

There are perhaps two major factors which have had negative effect on life expectancy since 1949. One is the less healthy diet composition plus harder work. The other is the epidemic outbreak of schistosomiasis during the later 1950s and early 1960s. If untreated, it usually takes five to fifteen years for schistosomiasis to kill a person. The flukes are parasitical on snails (thus the disease is also called "snail fever"). If one has contact with infected water the flukes may invade the body by getting into the blood circulation. For some unexplained reason, schistosomiasis became rampant during the 1950s. Mao's massive movement of wiping out snails, plus free treatment for all in the early 1960 s did put a stop to the epidemic. But the disease still has some effect up to the present. ${ }^{39}$

Income.There is no official record of personal income of the villagers before 1949. We can only compare the Mao era with the post-Mao reform period. In a normal harvest year, that is, when there was no serious crop failure, the average annual income per capita in Gao Village between 1978 and 1992 was $450 \mathrm{RMB}^{40}$ This, compared with an average annual income of 250 RMB per capita during the 1949 to 1978 period, was a considerable improvement. ${ }^{41}$ However, the rise of 
income is largely due to price adjustment rather than an increase in grain production. In other words, during the post-Mao reform period, the government's effort to raise the price of grain to narrow the price scissors's gap between industrial and agricultural products increased cash income at face value. ${ }^{42}$

However, in the case of Gao Village, by the early 1990s this increase of cash income is a mirage rather than a reality. The reason is simple: after paying various kinds of tax which takes away 20 percent of their annual produce, the peasants do not have any extra grain to sell in return for cash. ${ }^{43}$ In other words, the rise in income as a result of a price increase is largely nominal. If the villagers can manage to save some grain for sale when the harvests are good they have to use that money to pay for the debt incurred during the time of crop failure. Just like the years in Mao's era, the tiny amount of disposable cash income can only come from the sale of pigs and a limited amount of economy crops such as cotton. The villagers cannot afford to allocate much land to grow economic crops because they need the land to produce grain to feed the family.

\section{Migrant Work and Its Impact}

Gao Village has had a brief honeymoon with the post-Mao reform policies during the early 1980s when prices of agricultural produce were raised dramatically, when the prices of industrial goods did not follow the increase and when the local authorities had not yet started various kinds of taxes and levies. However, since the late 1980s the situation began to deteriorate rapidly. ${ }^{44}$ It is migrant work which has not only sustained life in Gao Village but also boosted consumer spending and thus increased the living standards, that is, if the consumption of commodity goods is taken to be a criterion.

From as early as the Taiping Peasant Uprising to Sun Yat- sen's Three Principles of the People, and to the communist revolution in the 1930s and then in 1949, equal distribution of land had been thought to be the most fundamental solution to China's problems. ${ }^{45}$ What happened in Gao Village in the late 1980s and early 1990s, however, does not seem to support this assumption. For one thing no form of land ownership can eradicate the poverty trap if the increasing population has to rely entirely on the limited land resources. By the late 1980s, land in Gao Village had become a burden 
for taxes and levies. A couple of villagers wanted to give land away. ${ }^{46}$ They would prefer to pay $100 \mathrm{RMB}$ to someone to take one $m u$ away. In return they only asked those who rent the land to pay the taxes and levies imposed on that $m u$ of land. It simply does not pay to work on the land any more for basically two reasons: One reason is that the cost of fertilizers and pesticides is so high ${ }^{47}$ while the price of grain is so low, thus comparing the two the effort does not create much of a reward. ${ }^{48}$ The other reason is that various taxes imposed on land are so high that working on the land is punitive. ${ }^{49}$

In Gao Village, for every $m u$ of rice it costs more than $100 \mathrm{RMB}$ of input, excluding labour. Take the case of Gao Changxian who is thirty-seven and married with three children. With his mother living with him there are six people in the family. He has four $m u$ of paddy fields and two $m u$ of dry land on which he grows cotton and rape seeds. Four $m u$ of rice yields 2,000 kilograms which gives him 832 $\mathrm{RMB}$, two $m u$ of dry land yields fifty kilograms of ginned cotton which gives him an income of $300 \mathrm{RMB}$ and 300 kilograms of rape seed which gives him $360 \mathrm{RMB}$. The total yearly income is therefore 1,500 RMB. Input costs are eighty RMB for seed and $648 \mathrm{RMB}$ for various chemicals. The average annual taxes and levies are eighty RMB per person, which total to 480 RMB for Gao Changxian's family. Their net income in an average year is only $292 \mathrm{RMB}$. He and his wife each spends 180 days in the field, which means that they each earn $0.8 \mathrm{RMB}$ a day, which is about \$US $0.4^{50}$

\section{Government Policies}

Since the late 1980s, the Chinese government has demanded every level of local authorities to adopt what is called caizheng baogan zhi (financial responsibility system) which basically means that the local authorities should be responsible for their own financial income and expenditure. This policy has two major consequences. One is the increasing shrinkage of expenditure on education, health and infrastructure, a phenomenon widely reported in the Chinese press. ${ }^{51}$ The other consequence is that local authorities began to impose all kinds of taxes and levies on the peasantry to raise financial income.

The exploitation of the peasantry is, of course, not new to the post-Mao regime. According to one estimate, the amount exploited from the peasantry by way of a different pricing system imposed on agricultural and industrial goods in 1957, 1965, 1971 and 1978 were respectively 71 percent, 75.77 percent, 51.6 percent and 39.4 percent 
of the Chinese government's financial income. ${ }^{52}$ Exploitation of the peasantry has always been the practice by the $\mathrm{CCP}$ government. What is new, however, is the arbitrariness of creating new levies and the corrupt practices by which the levies are spent by the local authorities. ${ }^{53}$

The Chinese government cannot do much about the situation. Premier Li Peng, for instance, emphasized at a planning and finance meeting on December 9, 1991 that the total taxes and levies on agriculture should not exceed 5 percent of a peasant's annual income. ${ }^{54}$ However, until recently the central government has done little to alleviate the burden on the rural people. ${ }^{55}$ In any case, given the present political and economic structures it is difficult to see what the Chinese government can do to remedy the situation. As we can see in Gao Changxian's case, taxes and levies amounted to 32 percent of his family's annual income.

\section{Migrant Workers}

As the rural situation began to deteriorate since the late 1980s, developments along coastal China also began to have an impact on Gao Village. The development of Special Economic Zones and for eign investments as a result of the post-Mao opening up policies have provided opportunities for rural young people to earn cash income. Although working conditions are primitive and even dangerous, and although these rural migrant workers have to work ten to fourteen hours a day and six or seven days a week to earn $200 \mathrm{RMB}$ to $400 \mathrm{RMB}$ a month they are willing to leave their home and ready to plunge into the unknown world. They are willing because working conditions at home are no more pleasant while earning far less. It is a combination of these "pull" and "push" factors that have created a situation in which for the first time in the history of Gao Village a breakthrough is possible to stop the involutionary rural development.

By 1992, fifty-two young people, mostly men, had left Gao Village as migrant workers and in 1994, when I visited the village again a dozen more including several girls had left. They want to leave because that is the only way out for them. Some of them have not left yet simply because they do not know where and how to go. ${ }^{56}$

Migrant work has influenced life in Gao Village in many ways, some immediately visible and some far-reaching. The most visible and immediate impact is of course the cash remittances from migrant workers. On average, every migrant worker sends 1,000 RMB to 2,000 RMB to Gao Village annually. For a variety of reasons such 
as family bonds, economic imperatives and a discrepancy of use value of the small amount of money between the urban and the rural, most of the migrant workers do send their earnings home. Of the ones I have interviewed only four teenagers do not send money home regularly. Instead, they spend the money on food, clothing and gambling. 1,000 RMB may not sound much to urban residents, but it has a considerable economic leverage on rural life. It is the remittance of the migrant workers that helps pay the debts, purchase consumer goods and build new houses, as discussed previously. Indeed, by the early 1990s it is difficult to imagine how Gao villagers sustain their life without the income from migrant workers.

Other impacts are far-reaching and more difficult to measure but can only be generally discussed at this stage. For instance, it is the first time in Gao Village history that life is not entirely dependent on land. As indicated previously, for many of them land has become a burden of taxes and levies. If the present policies are to continue, more and more young people will leave the village, as a result of which the pressure of a livelihood placed on the limited amount of land available due to the increasing population will diminish.

There is already evidence of a break-up of self-sufficiency in Gao Village. In May 1994 when I visited the village I was surprised to find that the villagers had to purchase agricultural produce such as cabbage, beans and garlic for their own consumption from a nearby marketplace three kilometres away. Formerly, they would grow all these things themselves. Or if they did not, like some families who did not have enough resources, they would simply have to do without. Village families also used to make beancurd for self-consumption. But now they purchase this common food from a specialized household or market. On the one hand they can afford to buy other people's labour and on the other there is the beginning of a local division of labour and local market exchange. A further indication of commercialization is that village shops have emerged everywhere in the area. There is also one such shop in Gao Village selling anything from light industrial goods to vegetables. All these could not have happened without the extra cash income coming from outside the village.

Equally important is the demographic impact, which involves several aspects of development. The rural people usually marry young, which means fertility rates are high. However, migrant 
workers delay their marriage for a number of reasons. First, as migrant workers, they are preoccupied with "making money". Secondly, there is less chance of making contact with the opposite sex since most factories have single sex work force and single sex dormitory. Thirdly, their experience and exposure to urban life make them less inclined to accept arranged marriages at home. One girl I interviewed declared simply that she would never get married because she wanted freedom. There is also the possibility that those young people may not want to return once the hukou system is relaxed. If 20 percent of the people in Gao Village, all of them young, continue to leave the village and never return, the demographic ramification is very great.

The other impact is the change of attitude and way of thinking. During the early 1980s soon after the dismantling of the commune system, all sorts of age-old customs such as arranged marriage, clan worship, village feuds came back with great force, as if the suppression of those customs in Mao's China in forty years had been blown away by a single storm. Also banditry and robbery were increasing rapidly in the area.

As an example of these phenomena, take one case of village feuds. In 1989, the people in Jin Village which has more than 3,000 households, had a fight with a nearby small village. They used homemade cannons and grenades and killed seventeen people from the small village. When the county authorities and police came to investigate, a disabled man in Jin Village declared that he and he alone was responsible for the killing. He agreed to shoulder the responsibility for the village because he felt that there was not much left in his life for a disabled man. In return the village agreed to look after his family while he was in prison. The astonishing thing was that the county government and police were powerless to do anything other than accept the offer. It was a laboratory model of circular development: The area where Gao Village is situated has returned to 1949 when the communist revolution began, that is, the inaccessibility of the state and the powerful rule of the clan system.

However, by the early 1990s it became quiet on those fronts without any state intervention. The reason is that in the area where Gao Village is located, more than 20 percent of the population had left, all of them young. ${ }^{57}$

Most migrant workers return home for the Spring Festival every year. There is some evidence that they are not interested in the old 
ways of doing things any more even when they get back home. During the Spring Festival of 1992 when I was in Gao Village, the village elders had trouble getting enough people to carry out the clan worship ceremony. The young people who returned from migrant work turned a deaf ear to the elders who were trying to talk them into organizing resources to fight a neighbouring Wang Village over a border dispute. One old villager who enjoys the most respect in the village turned to me for help to vitalize the village spirit for a fight.

\section{Conclusion}

In this study of Gao Village a general comparison is made between Mao's era and the post-Mao reform period in terms of personal income, housing, land holding, grain production, child mortality, food consumption and diet composition, education and health care. The comparison shows that post-Mao agricultural reform policies have not resulted in substantial improvement in personal income, housing, grain production and food consumption. The only real improvement is reflected in the availability of some consumer items, thanks to the industrial development since the 1980s. However, this gain is largely offset by losses in the areas of education and health care. All in all then, living standards have not been improved as a result of post-Mao de-collectivization policies. The responsibility system does give the peasants some freedom to do what they want with their plots of land and their produce. However, this freedom has not been translated into liberation of productivity; nor has it given rise to improvements in the quality of life. Patterns of economic and social structure similar to those before 1949 have come back. By the late 1980s only the levies and taxes by the local authorities became more arbitrary.

Though there is no substantial data to compare the forty years of communist China with the time before 1949, a comparison can be drawn in some respects. In housing and land holding, the villagers became worse off. This is a result of the population increase which itself is a result of the reduction in child mortality. As we have seen, the effect of the change of the economic system in the child mortality rate is marginal. Rather, the reduction of child mortality rate is a result of accessibility to modern medicine. Whether any regime other than the communist has the political resources to make modern 
medicine accessible to the peasants is an issue that cannot be pursued here. But the successful control of the schistosomiasis epidemic in the late 1950s does indicate that strong administrative measures are needed to organize the peasants to accomplish something substantial. In any case, the dramatic reduction of child mortality has led the villagers into a population trap which offsets any increase in grain production; and the post-Mao household responsibility system itself did not help population control in Gao Village.

In terms of the economic system, forty years of development has come full circle: the way by which individual plots are cultivated by households is the same as before 1949. In terms of living standards, forty years of development has been involutionary: with regard to important indicators such as housing and food consumption, the villagers are not much better off until the early 1990s. The increase of grain production as a result of hard work plus the introduction of new technology, which itself has serious ecological consequences, have been offset by the population explosion. The only substantial improvement in terms of education and health care in the Mao era has been set back by the post-Mao reform policies. Unless there is some structural change in the source of income it is hard to envisage a way to break the self-perpetuating poverty trap aggravated in Gao Village by the population trap.

The change in the income source seems to be within the reach of Gao villagers by the early 1990 s as a result of industrial expansion far away from Gao Village. It is this industrial expansion that on the one hand absorbs the surplus labour from Gao Village and on the other enables migrant workers to earn cash income for the village on the other. The cash income from migrant workers has already initiated the process of commercialization and has started the break-up of self-sufficiency though no sign of qualitative change in production can be detected. The impact of migrant work is manifested not only in economic terms but also in political and sociological terms. While the economic impact is visible and immediate in terms of balancing the family budget and increasing consumer expenditure, the political and sociological impacts are less tangible and very difficult to assess at this stage. It is far from certain whether China's industrial development can be sustained at the present rate, which has direct consequences for Gao Village. Uncertain also is the direction which the Chinese government will take with respect to the hukou 
system and agricultural policies. If, for instance, China's industrial expansion continues and if those migrant workers who left the village are allowed to settle where they work, then Gao Village as an economic entity will gradually phase out of existence. It is my understanding that the Great Leap Forward could be interpreted as an attempt to break the rural poverty trap. But it ended in disaster. However, the 1990s, for the first time in Gao Village history, have provided the possibility of breaking the self-perpetuation of rural development.

Dr. Mobo C. F. Gao is in the Department of Modern Languages, University of Tasmania, Australia. An early version of this paper was presented to the Biennial China Studies Association of Australian Conference held in Armidale in July 1992. The author has delayed submission for publication of the paper because it was felt that further investigation was needed for recent developments in the late 1980s and early 1990s in Gao Village. He would like to express gratitude to the anonymous reader and Professor Peter Lisowski, who not only polished the English but also made other valuable comments. Finally, he would like to thank Griffith University for providing a university grant and a study leave for the project of this paper.

\section{NOTES}

1 Y. M. Yeung and David K. Y. Chu, eds., Guangdong, Survey of a Province Undergoing Rapid Change (Hong Kong: The Chinese University Press, 1994).

2 In this respect see $W$. Hinton, The Great Reversal: the Privatization of China, 1978-1989 (New York: Monthly Review Press, 1990).

3 For the theory of involutionary rural development in traditional China see Philip Huang, The Peasant Family and Rural Development in the Yangzi Delta 1350-1988 (Stanford: Stanford University Press, 1990).

4 Personal recollections and experiences are difficult to scrutinize as to their "objectivity" and I am ready to admit possible "bias". I hope the present study will lead to an examination and reexamination of similar circumstances so that we may come to a better understanding of what has happened in China.

5 Xiang is the lowest rural administration unit staffed by government paid officers. The size of a xiang is roughly the same as that of a commune during the Mao-period.

6 Apart from interviews, I also examined written records such as account books of Gao Village and the brigade concerning the period from 1949 to 1979 when the commune system was dismantled. Many of the documents were dug out from dusty and dark corners of the house of those who were in charge of keeping them. During the field work, either in Gao Village or Xiamen and Shenzhen, I had no interpreters or official company. Because of personal contacts, no censorship of any kind was imposed. 
Mobo C. F. Gao

7 One $m u$ of land equals 0.0667 hectares.

8 There is no official record available for the statistics before 1949. The figures in this paragraph are based on field work and interviews.

9 A sishou teacher used to work at his (not her!) own home and gave informal tuition to village pupils and in return was paid by whatever kind of produce the pupil's family could offer. The teaching materials were of course classic Confucian textbooks. Gao Tianqiang did not work with his hands to produce grain and therefore was considered to be an exploiter.

10 The village has $28 m u$ more land as a result of reclamation over the years, which has exhausted the limit.

11 On November 5, 1993, the CCP and the State Council jointly issued a document Zhonggong zhongyang guowuyuan guanyu nongye he nongcun jingji fazhan ruogan zhengce cuoshi (Several policy measures by the $\mathrm{CCP}$ and the State Council concerning agricultural and rural economic development). One of the measures was zengren bu zengdi, jianren bu jiandi (no increase of land for the increase of household members and no reduction of land for the reduction of household members).

12 Again, these statistics were obtained from interviews and there is no official record available at village level,

13 Until the early 1980s when population control policy started to be rigorously implemented, birth registration was not an issue that concerned the local government much. Women had, and still have, babies at home, helped by a local midwife. Therefore, there is no official record available for the babies born during this period in Gao Village. The figures were obtained through interviews.
$14 \mathrm{My}$ mother had given birth to sixteen children. Three of the four born after 1953 survived and out of the ten born before 1953, only one survived.

15 This took place after Mao criticized the Ministry of Health as "the Ministry for the Urban Lords".

16 However, whether any regime other than the Communist would have had the power and mechanism to introduce modern medicine to villages like Gao is another issue.

17 Interviews with Gao Village Committee member Gao Changquan and Gao Changxian in May 1994.

18 In this respect see, for instance, David Zweig, "Prosperity and Conflict in Post-Mao Rural China," China Quarterly (March, 1986), No. 105, pp. 1-18. Also see Renmin Ribao, Overseas Edition, October 7, 1992, p. 1; and May 11, 1993, p. 5.

19 The issue of population control policy is very complex. For one thing, the central government in the past decade changed many times its administrative measures to control population growth. At the same time, local governments at every level were allowed to work out their own ways of carrying out the principle of birth control. Therefore, there were all kinds of flexibility and variation in population control measures, depending on time and place. In this respect see S. H. Potter \& J. M. Potter, China's Peasants: The Anthropology of a Revolution (New York, Port Chester, Melbourne and Sydney: Cambridge University Press, 1990).

20 The figures here were obtained from field work and interviews.

21 In this respect see Glen Peterson, "State Literacy Ideologies and the Transformation of Rural China," The Australian Journal of Chinese Affairs, (July, 1994), No. 32, pp. 93-120. 
22 I say "almost" because there were usually three ways a villager might be able to escape the fate of rural life. One was to compete to be recruited into the army. In forty years, three men left Gao Village in this way. The second way by which a villager might leave permanently was to be recruited as a worker. Two men in Gao Village who had finished secondary education were lucky enough to have become workers in the early 1970s during the Cultural Revolution. Finally, a village could, in theory at least, compete to enter a tertiary institution and thus be able to lead the envied urban life. That was of course very difficult if not impossible unless there is some kind of equity policy, like the one imposed during the Cultural Revolution. As for the young girls, until the early 1990s, the only chance for them to leave the condemned rural life was marriage, which occurred occasionally.

23 Gao Chaozhen, Gao Village Submission for the National Population Survey, 1991 (draft version), p. 3.

24 These figures were given by the village teacher Gao Chaozhen in the interviews in 1992.

25 For the rural poor the government's law of compulsory education is something on paper that will have no significance in their life unless there is financial assistance and an alternative career opportunity. In Gao Village, no financial assistance is available for even the poorest. Real alternative career opportunity had not occurred until the late 1980s and early 1990s. Caused by feedback from the coastal South indicating that the better you are educated the more chance you will have to be employed and to have a well-paid jobs, more and more families are struggling to send their children to the school in nearby village for education beyond year three. It is still too early to evaluate statistically the effect of this trend, which appeared in the early 1990s.

26 This information is based on personal experience. I was a teacher in Gao Village for three years during the early 1970 s.

27 This is calculated on the basis of my personal experience when I was living in the village.

28 There is no statistics available in the village. The estimate is based on interviews with the villagers and consumption patterns of my brothers' families.

$29 \mathrm{My}$ mother used to tell us again and again a story of how the landlord once carried a pig and gave it to her family after he had heard that my mother had no meat for the Spring Festival.

$30 \mathrm{As}$ we have seen previously, the most notable indication that the peasants were worse off before 1949 is that they could not do much if their children fell ill because there was no modern medicine available.

31 The number of working days is taken from the village account books. As for the hours and hard work on irrigation organized by the commune, I myself had experienced them. One would assume, as one anonymous reader of this paper reminds, that working days during the commune period were inflated as a result of a lack of incentives. Given the nature of agricultural work in Gao Village, whether one works hard is very difficult to quantify. From my own experience, however, a lack of incentives did not seem to be a major problem in Gao Village during the commune period.

32 Again, there is no official record for this. This conclusion was drawn 
after repeated interviews during which the villagers I interviewed recalled and counted what they could remember. From my own experience in Gao Village, floods were of routine life.

33 In Boyang County, which has a population of a little more than one million by the late 1980 s, more than 3,000 irrigation projects were carried out in the 1949 to 1989 period. Some projects were very large and tens of thousands of people were involved. One such a project in 1975 involved one hundred thousand peasants. In forty years, more than two hundred and thirty million labour-days were mobilized in irrigation work in Boyang County. See Zheng Chaojing, Hong Laishun and Li Bingcai, eds., Boyang xian shuili zhi (The Irrigation Annals of Boyang County) (Shanghai: Tongji Daxue Chubanshe, 1992), p. 4.

34 Compared with neighbouring villages Gao Village is in a very disadvantageous position in this respect. Because of the location of the village, it takes an enormous amount of work to build a dam to protect the small amount of the village land. For this reason during the commune period, the local authorities never thought it worthwhile to organize sufficient manpower to build a dam for Gao Village. On the other hand, because of the structure and organization of the commune system, Gao villagers had to send able men and women almost every year during the 1960 s and 1970 s to carry out irrigation work that benefited other villages (with no compensation). Gao villagers are still resentful about this fact. They think this was not only because Gao Village was too small to have any influence in decisionmaking but also because Gao Village had no connections in the power structure. As a matter of fact, the two factors are interconnected: local leaders are never chosen from a small village like Gao Village. For more detailed discussion on the local power connections and how it effects Gao Village see Mobo Gao, The Development of Gao Village since 1949: A Case Study (London: Hurst and $\mathrm{Co}_{\text {., forthcoming ). }}$

35 This picture is based on my personal experience and recollections.

36 Information obtained from interviews.

37 For this information $I$ had to ask the old villagers during my interviews to recall one by one who lived until when.

38 Gao Village household registration book.

39 In one of the worst effected areas, Yugan County in Jiangxi Province, twenty villages were wiped out of existence by the disease. In 1956, under Mao's directive, a task force committee was set up and was headed by Ke Qingshi. By mid 1958 the epidemic was under control. See Wu Xiaomai and Liu Lian, Mao Zedong zouchu honggiang (Away From the Red Walls: Mao Zedong on Tour) (Beijing: Zhongyang Dangxiao Chubanshe, 1993).

40 In 1991, the national average personal income in the Chinese countryside was 710 RMB. But in the same year there were sixty million Chinese peasants whose personal annual income was about $200 \mathrm{RMB}$ which is said to be the official Chinese poverty line (see, The Economist June 6, 1992, p. 26).

41 The former figures is taken from the village account book. The latter figure is calculated on the basis of interviews.

42 In 1979, the price for agricultural produce was raised by 25 percent to 40 percent. Furthermore, the amount of compulsory purchase of grains by the state was also re- 
duced. See James Kaising Kung, "Food and Agriculture in Post-Reform China, the Market Surplus Problem Revisited," Modern China, Vol. 18, No. 2 (April 1991), pp. 138-70.

43 For the amount of taxes and levies imposed by the government and local authorities during the late 1980 s and early 1990s and their effects on the farmers' life in Gao Village, see Mobo C. F. Gao, "Migrant Workers from Rural China: Their Conditions and Some Social Implications for the Economic Development in South China," in David Schak, ed., Entrepreneurship, Economic Growth and Social Change: the Transformation of Southern China (Nathan: Centre for the Study of Australia-Asia Relations, 1994), pp. 21-38.

44 See China News Analysis, (April 1993), No. 1483 and (September 1993), No. 1492.

45 See, for instance, R. H. Tawney, Land and Labour in China (London: Allen \& Urwin, 1932); and J. L. Buck, Land Utilization in China (New York: Paragon Book Reprint Corp., 1964).

46 It is worth observing what Fei Xiaotong had to say in 1947: "The levies on the peasantry were such that grain producers cannot make a living any more. Thus a strange phenomenon occurred: those who do not produce grain have grain to consume whereas those who do do not. In order to live the peasants have to leave the land. This is happening everywhere recently" (My own translation). See Fei Xiaotong, "Lun cheng, shi, zhen," (On the City, the Market and the Town), in Fei Xiaotong, Xiangtu chongjian (The $\operatorname{Re}-$ Construction of the Countryside) (Shanghai: Shanghai Guanchashe, 1948), p. 39.

47 As for the reasons of why the price of chemicals is so high, see Chen Feng, "Huafei de shengchan, gong- ying he xiaoshou de genben wenti ji chulu" (The Fundamental Problems underlying the Production, Supply and Sales of Chemical Fertilizers and the Way Out) in Gaige sikao (Contemplating the Reform) (Beijing: Zhongguo zhuoye chubanshe, 1992).

48 Traditionally, the major crop in the area is rice. There are three main factors hindering the villagers' decision to grow economy crops which may fetch a higher price. One is that they need enough grain to feed themselves. Another is the difficulty of finding a ready market, and finally it is the lack of accessible technology.

49 The punitive nature of farming is not only confined to Gao Village. It was reported in the Chinese official press that even in prosperous Zhejiang province peasants are not rewarded for producing grain. Zhuo Shengshan in Songdao xiang of Ningbo city was a famous grain producer who contracted $250 \mathrm{mu}$ of land for grain production. Since 1990 he ran a loss every year and now his debts has reached 120,000 RMB. See Cai Jizheng and Jiang $\mathrm{Li}$, "Zhongliang dahu weihe biancheng fuzai dahu" (How did a big grain producing household become a big debt household), Ban yue tan, 1994, No. 19, pp. 32-33.

50 This example of Gao Changxian is also cited in Schak, ed., Entrepreneurship, Economic Growth and Social Change.

51 Also see A. Saith, ed., The ReEmergence of the Chinese Peasantry: Aspects of Rural Decollectivization (London: Crown Helm, 1987).

52 Wang Guichen and Xiao Decheng, Zhongguo nongye chanye jiegou (Productive Structure in Rural China) (Beijing: Renmin Chubanshe, 1991) p. 54.

53 See Lai Ruihua and Jiang Xiexin, Zhongguo nongye zijin wenti yanjiu 
Mobo C. F. Gao

(The Problems of Funding Agriculture) (Beijing: Renmin Daxue Chubanshe, 1991). Also see Gao cited above for case study in this respect.

54 According to The China Daily, March 19, 1993, Vice-Premier Zhu Rongji stressed again that all the existing taxes and levies except the authorized 5 percent imposed on farmers should be stopped right away. But he stopped short of presenting any measure to do this.

55 On March 18, 1993, Renmin Ribao published a directive by the Ministry of Agriculture which prohibits ten ways of taxing the peasants by local cadres. However, as the old Chinese saying goes "Tian gao huangdi yuan" (The heaven is high up and the emperor is far away), so whether these kinds of measures are effective remains to be seen.

56 For the conditions of migrant workers and their earnings see Gao (1994) cited above and also Gao, "Welfare Problems and Needs for Migrant Workers in South China," in Joseph Cheng and Wing Lo, eds., Welfare in South China (forthcoming).

57 The figure of Yinbao xiang, which has a population of 20,000 , was given to me by the head of the xiang government Jin Shihui during an interview in December 1992. 